\title{
Pengaruh pembiayaan produktif mudharabah perbankan syariah terhadap pertumbuhan ekonomi Provinsi Jambi
}

\author{
Dedi Afriyandi F*; Amri Amir; Ridwan \\ Prodi Ekonomi Pembangunan, Fak. Ekonomi dan Bisnis, Universitas Jambi \\ *E-mail korespodensi: dedi_afriyandi@yahoo.com
}

\begin{abstract}
This study aims to analyze the trend of productive financing of Islamic banking mudharabah in Jambi Province, to analyze the dominant productive financing of mudharabah from Islamic banking in Jambi Province, and to analyze the effect of productive financing of Islamic banking mudharabah on economic growth in Jambi Province. This research uses descriptive and quantitative analysis methods. Based on the results of the analysis of trends in the development of productive financing of mudharabah banking, Jambi Province quarterly during 2010-2014 was included in the positive category, and the most dominant mudharabah productive financing in Jambi Province for the quarterly during 2010-2014 was working capital financing and during 2010-2014 productive mudharabah has a significant and positive effect on economic growth in Jambi Province.
\end{abstract}

Keywords: Productive financing the sharia banking, Economic growth

\begin{abstract}
Abstrak
Penelitian ini bertujuan untuk menganalisis trend pembiayaan produktif mudharabah perbankan syariah di Provinsi Jambi, menganalisis pembiayaan produktif mudharabah yang dominan dari perbankkan syariah di Provinsi Jambi dan menganalisis pengaruh pembiayaan produktif mudharabah perbankan syariah terhadap pertumbuhan ekonomi Provinsi Jambi. Penelitian ini menggunakan metode analisis deskriptif dan kuantitatif. Berdasarkan hasil analisistrend perkembangan pembiayaan produktif mudharabah perbankkan syariah Provinsi Jambi pertriwulan selama Tahun 2010-2014 masuk dalam kategori positif dan pembiayaan produktif mudharabah yang paling dominan di Provinsi Jambi pertriwulan selama Tahun 2010-2014 adalah pembiayaan modal kerja serta selama Tahun 2010-2014 menunjukkan bahwa pembiayaan produktif mudharabah berpengaruh signifikan dan positif terhadap pertumbuhan ekonomi di Provinsi Jambi.
\end{abstract}

Kata kunci: Pembiayaan produktif, Perbankan syariah, Pertumbuhan ekonomi

\section{PENDAHULUAN}

Pembangunan ekonomi suatu daerah pada hakikatnya merupakan suatu rangkaian kegiatan yang dilaksanakan secara sadar dan terus menerus untuk mewujudkan keadaan yang lebih baik secara bersama-sama dan berkesinambungan. Dalam rangka untuk memacu pemerataan pembangunan dan hasil-hasilnya guna meningkatkan kesejahteraan rakyat secara merata, maka keberhasilan pembangunan dapat diliha dari kenaikan pertumbuhan ekonomi dan pendapatan per kapita. Secara umum pertumbuhan 
ekonomi dapat diartikan sebagai suatu kondisi di mana terjadinya perkembangan GNP yang mencerminkan adanya pertumbuhan output perkapita dan meningkatnya standar hidup masyarakat (Murni, 2009).

Dalam usaha merealisasikan pelaksanaan pembangunan yang lebih baik pemerintah secara aktif turut campur tangan dalam proses pembangunan. Campur tangan pemerintah dalam berbagai kebijaksanaan biasanya dituangkan dalam rencana sosial yang menyeluruh mencakup seluruh aspek kehidupan masyarakat. Upaya pemerintah untuk mencapai tujuan ini ialah melakukan penetapan seperangkat kebijaksanaan nasional tercermin dalam konsep perencanaan pembangunan nasional (BAPPENAS). Rencana pembangunan yang jelas, dan tercermin dalam APBN akan mempengaruhi sektor swasta dan meyakinkan lembaga-lembaga lain mengenai apa yang akan ditempuh oleh negara yang bersangkutan dimasa yang akan datang dan lebih penting lagi adalah bahwa pemerintah yang bersangkutan harus lebih efisien dalam mengambil keputusan dimasa datang. (Irawan dan Suparmoko, 1998).

Dalam pelaksanaannya, pembangunan ini sendiri bukan hanya menitik beratkan kepada pertumbuhan ekonomi semata yang hanya mengarah kepada peningkatan produksi dan pendapatan nasional, tetapi ada indikator lain yaitu peningkatan pendapatan masyarakat melalui penyediaan lapangan pekerjaan, menurunnya angka kemiskinan dengan kata lain yang berujung pada kesejahteraan masyarakat. Kenaikan hasil produksi merupakan syarat mutlak yang diperlukan untuk memperbaiki dan meningkatkan standar hidup masyarakat, namun harus diakui adanya aspek-aspek lain yang turut menentukan eksistensi pembangunan seperti peran serta dari pihak swasta untuk menanamkan modalnya melalui investasi menunjukkan kecenderungan yang terus meningkat karena akan menciptakan tambahan pendapatan yang diakibatkan meningkatnya permintaan juga memperbesar kapasitas produksi melalui meningkatnya persediaan modal (Tan, 2009).

Pertumbuhan ekonomi daerah biasanya diindikasikan dengan meningkatnya produksi barang dan jasa yang diukur melalui Produk Domestik Regional Bruto (PDRB). Selama periode 2010-2015 pertumbuhan ekonomi di Provinsi Jambi menunjukkan kecenderungan yang meningkat. Kurun waktu 2010-2015 pertumbuhan ekonomi mengalami peningkatan yang cukup pesat, yaitu sebesar Rp.17.471.685,88 juta pada Tahun 2010, kemudian tumbuh sebesar 8,53 persen menjadi Rp.18.962.396,50 juta pada Tahun 2011 dan mengalami peningkatan menjadi 7,44 persen pada Tahun 2012 serta pada Tahun 2013 meningkat sebesar 7,88 persen. Hingga Tahun 2015 pertumbuhan ekonomi Provinsi Jambi meningkat sebesar 6,13 persen dibandingkan tahun sebelumnya menjadi sebesar Rp.24.875.330,64. Pertumbuhan ekonomi yang cukup tinggi sebagai akibat dari berkembangnya semua kegiatan di sektor ekonomi, tentu saja hal ini terjadi harus adanya dukungan dari kegiatan produksi dan investasi, termasuk di dalamnya adalah pembiayaan perbankan syariah.

Pertumbuhan ekonomi daerah secara langsung akan mempengaruhi pertumbuhan perbankan syariah. Jika perekonomian masyarakat daerah lesu, maka perbankan syariah di daerah tersebut akan mengalami kelesuan demikian pula sebalikya. Untuk itu perlu dilaksanakan kerja sama yang saling menguntungkan antara lembaga keuangan syariah dengan lembaga legislatif (DPRD), pemerintah daerah, masyarakat dan pengusaha daerah. Perlu program kemitraan antara bank dengan pengusaha di daerah, terutama usaha kecil dan menengah secara lebih mengakar dan berkelanjutan (sustainable), Muhammad (2005). 
Sehubungan dengan peranan perbankan syariah, tuntutan akan tersedianya sumber pembiayaan pembangunan di daerah telah mendorong pemerintah daerah dan DPRD untuk mempertanyakan kembali efektivitas pelaksanaan fungsi perbankan syariah sebagai lembaga intermediasi. Beberapa pihak perpendapat bahwa perbankan syariah tidak menjalankan fungsinya sebagai lembaga intermediasi di mana penyaluran pembiayaan pada perbankan syariah jauh lebih kecil dibandingkan penghimpunan dana. Penghimpunan dari dana pihak ketiga pada Tahun 2010 berjumlah Rp.552.000.000.000, Tahun 2011 berjumlah Rp.627.000.000.000 di Tahun 2012 berjumlah Rp.848.000.000.000 kemudian di Tahun 2013 berjumlah Rp.891.000.000.000. Pada Tahun 2014 meningkat berjumlah Rp.991.000.000.000, hingga Tahun 2015 berjumlah Rp.1.184.000.000.000. Angka ini jauh lebih besar dibandingkan penyaluran pembiayaan yang dilakukan oleh perbankkan syariah di Provinsi Jambi. Lebih lanjut dengan didasari kepada rasio penyaluran investasi bank syariah terhadap penghimpunan dana, berbagai pihak di daerah menyakini bahwa daerahnya mengalami "capital flight" karena dana yang diserap oleh perbankan syariah di daerah itu tidak disalurkan sebagai investasi untuk pembangunan di daerah yang bersangkutan, melainkan disalurkan sebagai investasi di daerah lain, (Siamat, 2010).

Kekhawatiran akan semakin sulitnya sumber pembiayaan pembangunan di daearah kemudian melahirkan berbagai pemikiran untuk mengoptimalkan seluruh resources khususnya sumber dana. Sumber dana yang dioptimalkan adalah sumber dana dari perbankkan syariah yang vital bagi pembangunan daerah. Perbankan syariah dalam melakukan aktifitas sangat memperhitungkan aspek keadilan dan aspek kondisi masa depan. (Antonio, 2006).

Hal ini sesuai dengan firman Allah SWT dalam Al-Qur'an Surat Luqman ayat 34:

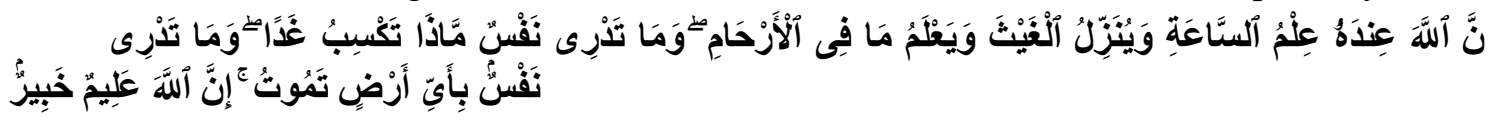

Sesungguhnya Allah, hanya pada sisi-Nya sajalah pengetahuan tentang Hari Kiamat; dan Dialah Yang menurunkan hujan, dan mengetahui apa yang ada dalam rahim. Dan tiada seorangpun yang dapat mengetahui (denganpasti) apa yang akan diusahakannya besok. Dan tiada seorangpun yang dapat mengetahui di bumi mana dia akan mati. Sesungguhnya Allah Maha Mengetahui lagi Maha Mengenal (QS.Luqman: 34).

Perbankan syariah Provinsi Jambi memegang peranan penting dalam aktifitas pembangunan daerah. Banyak aktifitas produksi yang di tunjang oleh perbankan syariah. Hal ini dapat dilihat dari meningkatnya jumlah pembiayaan yang diberikan oleh pihak perbankan terhadap kegiatan usaha produktif. Pembiayaan produktif mudharabah yang dikeluarkan pihak perbankan syariah di Provinsi Jambi menunjukan peningkatan. Pada Tahun 2010 jumlah pembiayaan produktif mudharabah yang diberikan pihak perbankan syariah baru mencapai Rp.216.452.750.000 namun sampai pada Tahun 2011 jumlah pembiayaan produktif mudharabah pihak perbankan syariah di Provinsi Jambi meningkat menjadi Rp.292.216.000.000 atau telah terjadi peningkatan menjadi 35,00 persen, sedangkan pada Tahun 2012 jumlah pembiayaan perbankan syariah mencapai Rp.389.370.000.000 serta pada Tahun 2013 jumlah pembiayaan produktif mudharabah meningkatsebesar 15,08 persen menjadi sebesar Rp.448.080.250.000, begitu hingga Tahun 2015 pembiayaan produktif mudharabah perbankkan syariah di Provinsi Jambi berhasil meningkat 14,62 persen menjadi sebesar Rp.1.020.445.192.334. 
Peningkatan peranan pihak perbankan syariah di Provinsi Jambi tercemin dari meningkatnya jumlah pembiayaan yang disalurkan. Keberadaan lembaga ini sangat penting, terutama pada posisi intermediasi.Upaya peningkatan peran serta perbankkan dalam pembangunan melalui penyaluran pembiayaan produktif syariah menunjukkan tinggi rendahnya peranan perbankkan syariah untuk peduli terhadap pembiayaan pembangunan. Dengan demikian akan mendorong sektor ekonomi yang pada akhirnya akan mendorong pertumbuhan ekonomi di Provinsi Jambi.

\section{METODE}

Untuk menjawab tujuan penelitian pertama yaitu mengetahui dan menganalisis trend pembiayaan produktif mudharabah perbankkan syariah di Provinsi Jambi. Rumus trend pembiayaan produktif mudharabah perbankan syariah di Provinsi Jambi adalahs ebagai berikut (Widarjono, 2009) :

$$
\begin{aligned}
& \mathbf{Y}=\boldsymbol{\alpha}+\boldsymbol{\beta} \mathbf{x} \\
& \alpha=\frac{\sum Y / N}{} \\
& \beta=\frac{\sum Y . X}{\sum X^{2}}
\end{aligned}
$$

Keterangan:

$\alpha=$ Konstanta

$\beta=$ Koofisien pembiayaan produktif mudharabah

Y : Jumlah pembiayaan produktif mudharabah

$\mathrm{X}$ : Tahun penelitian

$\mathrm{N}$ : Jumlah tahun penelitian

Untuk menjawab tujuan penelitian kedua yaitu mengetahui dan menganalisis pembiayaan produktif mudaharabah perbankkan syariah yang dominan di Provinsi Jambi selama Tahun 2000-2015 digunakan rumus berikut, (Sugiyono 2007):

$$
\text { KPMK }=\frac{\text { PMK }}{\text { Pprod }} \times 100 \%
$$

Keterangan :

KPMK = Kontribusi pembiayaan modal kerja terhadap total pembiayaan produktif mudharabah

PMK = Pembiayaan modal kerja

Pprod = Pembiayaan produktif mudharabah

PI

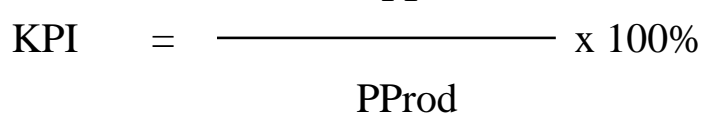

Keterangan:

KPI $=$ Kontribusi pembiayaan investasi terhadap total pembiayaan produktif mudharabah 
PMK = Pembiayaan investasi

Pprod $=$ Pembiayaan produktif mudharabah

Untuk menjawab tujuan penelitian ketiga digunakan analisis regresi sederhana sebagai berikut (Gujarati, 2003):

$\mathbf{Y}=\boldsymbol{\alpha}+\boldsymbol{\beta}_{1} \mathbf{X}_{1}+\mathbf{e}$

Dimana:

$\mathrm{Y}=$ Pertumbuhan ekonomi

$\alpha=$ Konstanta

$\beta 1=$ Koefisien regresi

$\mathrm{X}_{1}=$ Pembiayaan produktif mudharabah perbankan syariah Provinsi Jambi

$\mathrm{e}=$ Standar error

\section{HASIL DAN PEMBAHASAN}

Trend pembiayaan produktif mudharabah perbankan syariah di Provinsi Jambi pertriwulan Tahun 2010-2014

Hasil trend pembiayaan produktif mudharabah perbankan syariah Provinsi Jambi sebagai berikut:

$$
\begin{aligned}
Y^{\prime} & =\alpha+\beta x \\
\alpha & =\sum Y / N \\
& =\frac{8.945 .596 .760 .619}{20} \\
& =447.279 .838 .031 \\
\beta & =\sum Y . X \\
& =\frac{118.389 .747 .086 .649}{2.870} \\
& =41.250 .782 .957 \\
Y^{\prime} & =\alpha+\beta x \\
& =447.279 .838 .031+41.250 .782 .957 x
\end{aligned}
$$

Dari persamaan trend pembiayaan produktif mudharabah diperoleh nilai $\alpha$ atau hasil konstanta sebesar 447.279.838.031. Hal ini menunjukkan bahwa pembiayaan produktif mudharabah perbankan syariah di Provinsi Jambi selama Tahun 2010-2014 pertriwulannya rata-rata sebesar Rp.447.279.838.031.

Nilai $\beta$ dari persamaan trend pembiayaan produktif mudharabah sebesar 41.250.782.957, hal ini menunjukkan trend penerimaan pembiayaan produktif mudharabah perbankan syariah Provinsi Jambi termasuk trend positif, yaitu apabila $\mathrm{X}$ (waktu tahun) meningkat, maka nilai $\mathrm{Y}$ (pembiayaan) juga meningkat sebesar Rp.41.250.782.957.

\section{Pembiayaan produktif mudharabah perbankan syariah yang dominan}

Rata-rata kontribusi pembiayaan modal kerja terhadap pembiayaan produktif mudharabah perbankan syariah di Provinsi Jambi pertriwulan selama Tahun 2010-2014 
adalah sebesar 69,09 persen. Kontribusi terbesar adalah kontribusi pembiayaan modal kerja pada triwulan pertama Tahun 2010 yaitu sebesar 78,70 persen. Sedangkan kontribusi terkecil adalah kontribusi pembiayaan modal kerja pada triwulan keempat Tahun 2013 sebesar 57,50 persen. Besarnya kontribusi pembiayaan modal kerja pada triwulan pertama Tahun 2010 di sumbang oleh pembiayaan modal kerja UMKM. Jumlah UMKM yang menggunakan pembiayaan modal kerja adalah sebanyak 3.076 unit. Meningkat lebih besar dari tahun sebelumnya yaitu sebanyak 2.000 unit. Disisi lain penurunan kontribusi pembiayaan modal kerja pada triwulan keempat Tahun 2013 juga disebabkan penurunan jumlah UMKM yang menggunakan pembiayaan ini menjadi sebanyak 5.526 unit daris ebelumnya 5.160 unit.

\section{Pengaruh pembiayaan produktif mudharabah perbankan syariah terhadap pertumbuhan ekonomi Provinsi Jambi}

Pada hasil regresi dalam penelitian ini dengan menggunakan regresi sederhana di peroleh persamaan sebagai berikut:

$$
\begin{aligned}
& Y=\boldsymbol{\alpha}+\boldsymbol{\beta}_{\mathbf{1}} \mathbf{X} \mathbf{1}_{\mathbf{t}}+\mathbf{e} \\
& \log \mathrm{Y}=\alpha+\beta_{1} \log \mathrm{X} 1_{\mathrm{t}}+\mathrm{e} \\
& \log \mathrm{Y}=5,624+0,193 \log \mathrm{X} 1+\mathrm{e}
\end{aligned}
$$

Dalam persamaan regresi linear sederhana tersebut diperoleh atau didapat hasil konstanta yaitu 4,466. Hal ini bahwa jika pembiayaan produktif mudharabah perbankan syariah tidak mengalami perubahan atau tetap, maka pertumbuhan ekonomi Provinsi Jambi rata-rata adalah sebesa $\mathrm{r} 4,466$ persen.

Nilai koefisien regresi untuk pembiayaan produktif mudharabah adalah 0,193 , hal ini menunjukkan adanya pengaruh positif antara variabel pembiayaan produktif mudharabah dengan variabel pertumbuhan ekonomi Provinsi Jambi. Dimana bila terjadi kenaikan pembiayaan produktif mudharabahs ebesar 1 persen maka pertumbuhan ekonomi Provinsi Jambi akan naik sebesa r0,193 persen dengan asumsi variabel lain konstan.

\section{Hasil pengujian hipotesis}

\section{Uji signifikan sistatistik secara individual/parsial (uji t)}

Dari hasil pengujian diperoleh nilai $\mathrm{t}$ hitung untuk variabel pembiayaan produktif mudharabah sebesar 9,936dengan tingkat keyakinan $95 \%$ atau $(\alpha=5 \%) \mathrm{df}=(18)$ untuk pengujian diperoleh nilai $\mathrm{t}$ tabelsebesar 2,100 dari perhitungan tersebut dapat dilihat bahwa nilai $\mathrm{t}$ hitung lebih besar dari $\mathrm{t}$ tabel $(9,936>2,100)$, artinya Ho ditolak dan Ha diterima artinya pembiayaan produktif mudharabah berpengaruh signifikan terhadap pertumbuhan ekonomi Provinsi Jambi. Dengan demikian hipotesis menyatakan terdapat pengaruh yang signifikan antara pembiayaan produktif perbankan syariah mudharabahdengan pertumbuhan ekonomi Provinsi Jambi benar dan terbukti.

\section{Uji secara simultan (uji F)}

Berdasarkan hasil regresi diketahui atau diperoleh nilai F-hitung sebesar 98,717 dan dengan tingkat keyakinan $95 \%$ atau $(\alpha=5 \%)$ df $=(18)$ diperoleh $\mathrm{F}_{\text {tabel }}$ sebesar 4,41.Dengan demikian nilai $F_{\text {hitung }}$ lebih besar dari $F_{\text {tabel }}(98,717>4,41)$. Hal ini dapat 
diartikan bahwa variabel bebas (pembiayaan produktif mudharabah) secara bersamasama (simultan) berpengaruh signifikan terhadapv ariabel tidak bebas (pertumbuhan ekonomi) di Provinsi Jambi.

\section{Koefisien determinasi $\left(\mathbf{R}^{2}\right)$}

Pada hasil perhitungan statistik diperoleh besarnya koefisien determinan $\left(\mathrm{R}^{2}\right)$ adalah 0,846 atau 84,6 persen ini artinya bahwa nilai $\mathrm{R}^{2}$ pada seluruh variabel independent/bebas yaitu pembiayaan produktif mudharabah perbankan syariah terhadap variabel dependent/tidak bebas yaitu pertumbuhan ekonomi Provinsi Jambi adalah sebesar 84,6 persen sedangkan sisanya 15,4 persen dipengaruhi oleh variabel lain yang tidak dimasukkan dalam penelitian ini.

\section{KESIMPULAN DAN SARAN}

\section{Kesimpulan}

Trend perkembangan pembiayaan produktif mudharabah perbankkan syariah Provinsi Jambi pertriwulan selama tahun 2010-2014 masuk dalam kategori positif. Pembiayaan produktif mudharabah yang paling dominan di Provinsi Jambi pertriwulan selama Tahun 2010-2014 adalah pembiayaan modal kerja. Berdasarkan hasil analisa selama Tahun 2010-2014 menunjukkan bahwa pembiayaan produktif mudharabah berpengaruh signifikan dan positif terhadap pertumbuhan ekonomi di Provinsi Jambi.

\section{Saran}

Peningkatan pembiayaan produktif perbankan syariah Provinsi Jambi yang telah terjadi lebih distabilkan oleh Bank Syariah di Provinsi Jambi agar dampaknya lebih dirasakan signifikan terhadap peningkatan ekonomi masyarakat Provinsi Jambi. Pembiayaan yang lebih dominan seharusnya pembiayaan yang mampu memberi dampak jangka panjang serta merupakan pembiayaan yang penggunaannya mampu menciptakan arus barang dan jasa yang baru. Penyaluran pembiayaan syariah yang dilakukan oleh pihak perbankan syariah Provinsi Jambi harus terus diawasi, agar setiap penyalurannya tidak hanya menjadi perbandingan secara nominal serta merupakan pembiayaan yang mampu menggerakkan pembangunan ekonomi daerah.

\section{DAFTAR PUSTAKA}

Al Karim. (1993). Al Quran dan Terjemahanya, CV Toha Putra: Semarang.

Antonio, Syafi'i. (2006). Bank Syariah. PT Ekonisia: Yogyakarta.

Badan Pusat Statistik. (2015). Jambi dalam Angka. Terdapat dalam http://bps.go,id diunduh pada Tanggal 12 Juni 2015 Pukul 16:30.

Bank Indonesia. (2014). Statistik Perbankkan Syariah. Terdapat dalam dalam http://www.bi.go.id/web/id.Syariah/ diunduh pada Tanggal 31 Juni 2015 pukul 15:58.

Gujarati, Damodar. (2003). Ekonometric. Erlangga: Jakarta.

Irawan, dan Suparmoko, M. (1998). Ekonomi pembangunan. BPFE: Yogyakarta.

Le Fitri, P Lubis, Aryd Amri.(2019). The determinants of customer loyalty in sharia bank in jambi with islamic approach, Maqdis: Jurnal Kajian Ekonomi Islam 4 (2), 129-142 
Muhammad. (2005). Ekonomi makro dalam perspektif islam. BPFE: Yogyakarta.

Murni, Asfia. (2009). Ekonomika makro. PT. RefikaAditama: Bandung.

R Ridhwan, Le Fitri, R Hidayat. (2019). The relationship of service quality, trust, and satisfaction of muslim patients in Arafah Islamic Hospital Jambi with Islamic Economic Approach, JEBI (Jurnal Ekonomi dan Bisnis Islam),4 (2), 239-253

Siamat, Dahlan. (2010). Manajemen lembaga keuangan. Intermedia: Jakarta.

Sugiyono. (2007). Statistika untuk penelitian. Alfabeta: Bandung.

Tan, Syamsurijal. (2004). Ekonomi pembangunan. Citra Indonesia: Jambi. 